Preprint (after editorial review): Kergomard, Zoé: Knowledge on a Democratic "Silence": Conflicting Expertise on the Decline in Voter Turnout in Postwar Switzerland (1940s-1980s), in: KNOW: A Journal on the Formation of Knowledge 4 (2), 2020, pp. 232-261.

\title{
Knowledge on a Democratic "Silence": Conflicting Expertise on the Decline in Voter Turnout in Postwar Switzerland (1940s-1980s)
}

\section{Zoé Kergomard}

In a 1975 speech, the socialist Swiss Federal Councilor (Minister) Willy Ritschard diagnosed a "crisis of government" in the decline in voter turnout in Switzerland since the 1940s. ${ }^{1}$ Indeed, the Swiss "people” seemed to have forgotten that "the Swiss constitution makes them the government.”2 Such a grim diagnosis by a familiar politician became a reference point in public debates, reflection a widespread discourse at the time on low voter turnout as one of Switzerland's most "urgent problems," which needed to be assessed and addressed by means of scientific methods. ${ }^{3}$ Notably, the instrumentalization of the decline in voter turnout as a seemingly objective - since it was quantifiable - symptom of a “democratic crisis” or even of a particular "post-democratic" condition foreshadowed public debates in many Western democracies since the 1990 s. ${ }^{4}$ It also contrasts with common representations of the period culminating in 1968 as a period of intense political participation beyond the election cycle, indeed as an era in which new social movements, particularly feminist activists and political theorists alike expanded concepts of "politics” and "participation” both in their practices and

in their writings. ${ }^{5}$ A now infamous report for the Trilateral Commission also diagnosed a "crisis of democracy” in 1975, but its three authors (social scientists Michel Crozier, Samuel P. Huntington, and Joji Watanuki) wanted - contrary to Ritschard - to warn of an "excess of democracy" leading Western governments to become "overloaded with participants and demands." 6

Beyond differences of interpretation, diagnoses on the state of democracy and participation in the 1970s built on decades of knowledge production on politics at the intersection of various and often conflicting - fields of expertise. Instead of retrospectively illuminating the state of 
Swiss democracy in the 1970s, Willy Ritschard's problematization of voter turnout requires an analysis of the interplay between knowledge production and public debates on democracy in the early decades of the postwar period. "Postwar democracy" as a construct is particularly saturated in models and interpretations produced both later and contemporaneously. More recently, it has often served as a counterpoint to contemporary narratives of democracy crisis, thereby crystalizing nostalgic and enchanted representations of a "mass party democracy" in which citizens were fairly represented by political parties. ${ }^{7}$ Works rooted in the history of ideas have instead highlighted a postwar (but pre-1968) model of "constrained democracy" essentially centered on elections, understood as the central tool for the stabilization and legitimization of the new political regimes. ${ }^{8}$ Yet the diagnosis (or the hopes) of postwar intellectuals did not always match political practices, as recent works on pre-1968 social movements and politics "from below" have argued. ${ }^{9}$ Furthermore, nineteenth century historiography has shown how the development of various forms of knowledge on politics and particularly on elections (from administrative reports to the beginnings of electoral statistics) contributed to the naturalization of elections as seemingly transparent procedures. ${ }^{10}$ Consequently, the "scientification"11 of postwar politics and particularly the development of political science and polling was not simply a side-product of postwar democracy, but contributed to shaping political discourses and practices during that time. Ritschard's seemingly obvious link between the decline in voter turnout and a crisis of democracy must therefore be historicized as a form of situated knowledge. Focusing on scientific studies and media pieces, ${ }^{12}$ this article charts the emergence of various (and possibly conflicting) forms of knowledge and interpretative frameworks on electoral turnout and participation, as well as their circulation in the public sphere and their potential influence on political action. The positions of "experts" in the political, the media and the academic fields are highlighted in order to consider the possibilities they may or may not have had to legitimize their expertise and to be heard in the public sphere. 
As in other Western European countries, political science developed in Switzerland after 1945, paralleling the development of commercial survey research. The first generation of political scientists at Swiss universities soon developed close links to commercial pollsters, with whom they worked on large electoral studies starting in the 1960s. At a time when this emerging discipline's epistemologies were rarely formalized, particularly in a smaller academic field such as Switzerland, they also maintained close ties to Swiss sociologists and historians. With the decline of party newspapers and the rise of independent commercial newspapers as well as of television in the 1960s, the demand grew within public debate for recognized forms of expertise on politics. As members of a comparatively young social science still in the process of institutionalization, political scientists stood to gain both visibility and legitimacy through media access or even direct political engagement, even if such encounters called into question their relationship to political actors - an especially relevant facet for a discipline that had emerged out of social science of public administration (Staatswissenschaften) and the training of civil servants. ${ }^{13}$

A consideration of postwar Switzerland thereby also elucidates both the interplay between the transnational circulation of ideas on democracy and the perpetuation (as well as transformation) of perspectives centered on the nation-state. The former became manifest in the work of the first generation of Swiss political scientists, who drew heavily on the research of their Anglo-American, German, and French colleagues. The latter entailed the construction of culturalist discourses reflecting an "exceptional" Swiss democracy with its roots in the medieval period. ${ }^{14}$ The importance of federalism and direct-democratic procedures was emphasized in an idealization of Swiss democracy as enabling all (male) citizens to participate equally in politics and in the army in addition to their professional occupation, following the republican idea of "militia". This exceptionalist narrative was cemented in the public discourse during the early postwar decades, as it supported the spirit of 
anticommunism widely held in politics and in the army. The exceptionalism of Swiss democracy, requiring so much of its men, also served as a key argument in legitimizing the refusal to grant women suffrage until 1971 at the federal level. Confronted with this highly political narrative, scholars and other experts did not hold to a singular line of interpretation. While French political scientist André Siegfried praised the "Swiss model” in a 1948 book funded by the state-supported Pro Helvetia cultural foundation, ${ }^{15}$ his colleagues in Switzerland attempted to theorize what truly made Switzerland stand apart, ${ }^{16}$ while also remarking on the shadows in the enchanted narrative - such as pointing out the decline in voter decline.

\section{A "laziness" and a "threat" to Swiss democracy}

As early as the 1940s, politicians, journalists and intellectuals noted a slight decrease in electoral participation, from a peak of $80 \%$ during the contentious $1920-1930$ s to a "mere" $70 \%$ of the population eligible to vote a decade later. In the postwar years, journalists and politicians ritually lamented that this change raised questions about the future of Swiss democracy. ${ }^{17}$ While the country had not directly taken part in World War II, contemporary commentators did not presume a seamless political continuity. On the contrary, the political conflicts of the interwar years, which had occasionally led to violence, lingered as a specter for many political elites, including socialists aiming at respectability. Not unlike in other countries, the desire to channel conflict put a strong emphasis on voting - in elections but also in direct-democratic votes. As early as the late 1930s, a series of collective conventions had outlawed striking as a legitimate means of employee action (the so-called “industrial peace”), and demonstrations were also becoming a rare means of action. For political elites, the early decline in voter turnout further raised the question of how to simultaneously maintain a pacified but dynamic political life. The calls of the Gotthard League, a patriotic association, for the maintenance of the war-time spirit of "unity" even during the 1943 electoral 
campaigns was not well received by right-wing party actors, as they linked it to the rise of voter abstention. ${ }^{18}$ Such concerns were accompanied by political demands for information on the social distribution, and ideally, the causes of this "problem," including a Zurich statistics office study commissioned in 1943 by the Zurich cantonal government. ${ }^{19}$ Since the beginning of the twentieth century, federal and cantonal statistics offices had established their expertise on voting by producing and analyzing electoral statistics. ${ }^{20}$ Thanks to its official commission, the Zurich office had access to voting documents from almost all polling stations and could establish the demographic profile of non-voters thanks to census data on profession, town of origin, age and religious affiliation. Based on statistical correlations, statisticians concluded that young, working-class, urban individuals were particularly prone to abstain from voting. In a still polarized political context, quantifying the unequal social distribution of voting was not merely a matter of record-keeping. The voting statistics, quantified by profession, were circulated in the press and were used by the socialists to urge "working-class" voters not to join the "party of non-voters" and instead to reclaim the "wheel of our state" from the "rich." ${ }^{21}$ Indeed, these statistics confirmed what many socialists - in Switzerland as in other countries - observed within the postwar working classes, namely "petty bourgeois" aspirations and consequently a loss of political consciousness. ${ }^{22}$ Nonetheless, these statistics still provided no explanation for the abstention rates. Statisticians tried to imagine possible causes and concluded that apart from "objective” hindrances such as sickness or absence, most non-voters had no "imperative reasons" to abstain. ${ }^{23}$ The study consequently presumed that their abstention was the result of a general "Gleichgültigkeit” toward politics - a term that can be translated as a feeling somewhere between indifference and complacency. ${ }^{24} \mathrm{~A}$ similar conclusion was drawn by a 1945 study on "non-voting as a danger to political sovereignty" commissioned by Redressement national, a right-wing lobby group. ${ }^{25}$ While its authors used Swiss electoral statistics to quantify the phenomenon, they referred to the pioneering survey study completed by American political scientists Charles E. Merriam and Harold F. Gosnell in 
the early 1920s in Chicago to understand the causes of non-voting. They assumed that a "general indifference” (translated as "allgemeine Gleichgültigkeit”) could also explain the "passivity" of non-voters in Switzerland - an all the more likely conclusion since Swiss citizens, unlike Americans, were automatically registered to vote in their jurisdiction of residence. $^{26}$

The early postwar discussion of abstention in Switzerland mirrors the frequent discussions in other postwar democracies about a particular "apathy"- including in the use of similarly negatively connotated vocabulary to describe non-voting in French (abstentionnisme) and German (Stimmabstinenz). Yet in particular in the American context (both among academics and in the media), prominent essayists and political scientists judged non-voting to be an acceptable part of an overall healthy political life, especially if it mostly affected less informed citizens. ${ }^{27}$ Conversely, the Swiss discussion framed non-voting not only as a moral failure to fulfill one’s "civic duty," 28 but also as a "threat" to democracy as a whole. Using morally charged qualifiers, the Zurich study thus compared the "dutiful zeal” (Pflichteifer) or "assiduousness" (Wahlbeflissenheit) of voters to the "laziness" (Faulheit) or even "laxness" (Laxheit) of non-voters. ${ }^{29}$ Considering the postwar context, certain political actors, such as the patriotic Gotthard League, worried that citizens could fall into a general "spirit of demobilization,” both in terms of their military and their political duties. ${ }^{30}$ Indeed, non-voting contradicted the ideal of the Swiss "citizen-soldier" who was glorified in Switzerland after 1945, personifying both the country's alleged self-defense during the war and the need to fight communism. ${ }^{31}$ While the link between voting and a (virile) combative and patriotic spirit was not unique to the postwar period nor to Switzerland, ${ }^{32}$ it was nonetheless commensurate with the repeated affirmation of citizenship and participation in the political sphere as an inherently male enterprise: after 1945, female suffrage was again discussed, but rejected in several cantonal votes. ${ }^{33}$ The dichotomy between activity and passivity mirrored 
gender hierarchies, not only between men and women, but also among men: for the Zurich study, only the act of voting could produce "veritable active citizens." ${ }^{34}$ Abstention devirilized men since it was a renunciation of their duty as citizens-soldiers and as patres familias representing their families, including their wives, in the political sphere.

\section{Political science and the quest for non-voters" "motivations"}

Starting in the 1950s, academics increasingly took on the role as the experts on non-voting, as both sociologists and the first generation of political scientists in Switzerland claimed the issue as an object of genuine scientific enquiry, even if they also acknowledged it as one of the "problems [...] worrying most Swiss political observers.”35 For Geneva sociologist René Girod, what mattered was thus "not to gather numbers, but to shed light on human behavior;" due to its federal structure, Switzerland thus constituted a "natural laboratory" in which to do so within different political constellations. ${ }^{36}$ At a crucial time for the institutionalization of their disciplines, such a positivist perspective on political behavior assured Swiss sociologists and political scientists scholarly legitimacy, as well as being in sync with the behaviorist orientation of Anglo-American political scientists. ${ }^{37}$ Beyond their varied sources of inspirations (Girod partly followed André Siegfried and the French tradition of electoral geography), they mirrored the preference expressed by their colleagues abroad for individual polling to better understand the psychological "motivations" of voters. Even if they had not spent part of their academic career abroad, it soon became imperative to quote international, at least French or German-speaking or, better yet, English-speaking reference works. Comparisons between political contexts thus emerged as a thought process, but also increasingly as a standard for social science methodology. ${ }^{38}$ Comparing turnout rates for parliamentary elections among Western democracies demonstrated that Switzerland, together with the USA, was "far from exemplary regarding [voting] assiduity.”39 
To understand the motivations of non-voters, Jürg Steiner and Girod led survey studies interviewing voters and non-voters around the country. Even if they did not always refer to the international scholarship, their conclusions reflect a common understanding of political participation centered on "legitimate” political activities, particularly voting. Not unlike Lester Milbrath’s “pyramid of participation” for instance, ${ }^{40}$ Steiner understood “participation” as a continuum between an "active" citizen, who not only voted, but also "diligently read the political part of the newspaper," listened to political talk shows on the radio, discusses politics, attended political meetings and potentially became an engaged member of a political party, and a "passive” one, who abstained from all such activities. ${ }^{41}$ According to Girod, nonvoting was generally not a "deliberate and well-decided act" of rejection, but was to be expected from "personalities who have little energy, little curiosity and who either live in a small, cozy and attractive personal universe (average citizen) or in a particularly disadvantaged social environment, that does not share the interests of the broader community and that is not well organized to assert its claims (agricultural workers, low-level employees, etc.)." ${ }^{42}$ Indeed, as a poll commissioned by the Agrarian Party concluded in 1962, non-voters were essentially "passive" citizens who tended to "retreat" into the private sphere. ${ }^{43}$ This explanation thus expanded the gender-based division between private and public, which played a central role in the debate over female suffrage, by differentiating between men.

Going further, Girod and Steiner analyzed this "retreat” as the consequence of a lack of social integration. This issue was only temporary in the case of youngsters, until they were able to fully engage in "adult life,” by which Girod meant "professional activities, marriage, children, etc." ${ }^{44}$ But it was possibly also a generalized urban phenomenon, which could account for the overall lower turnout rates observed in cities. Girod and Steiner thus started linking the general decline in turnout with the ongoing suburbanization of the country, particularly of the non-mountainous corridor from Geneva to St. Gallen. This explanation mirrored a 
transnational discussion at the turn of the 1960s on the consequences of "massification" on social integration. ${ }^{45}$ Similarly, the first studies produced by commercial polling institutes mandated by Swiss political parties drew a dramatic picture of "unrooted” suburban voters by referring to German studies about "Vermassung." 46 This diagnosis also reflected a particular, widespread nostalgia for intimate, unmediated “town politics” among Swiss political elites at the time. ${ }^{47}$ In a 1959 study based on interviews, Jürg Steiner depicted the loss of personal contact to politicians as a problematic change: voters in the city of Bern did not know their city councilors anymore. Spatial, but also social “mobility” made it difficult for voters to read the political landscape and to feel connected to a party. ${ }^{48}$ On the contrary, party affiliations in the countryside remained "stable," to the point that it was not uncommon for fathers to pay the party membership fee on their son's twentieth birthday. ${ }^{49}$ Through close contact with their constituents in local inns and community centers, countryside politicians were still able to provide "pastoral care,” address citizens informally (with "Du” instead of the more formal “Sie”) and offer counsel just as a pastor would, “if [someone’s] daughter was pregnant with an illegitimate child."50 This example reveals not only the social mores in the countryside around Bern as described by Steiner, but also the emphasis on having representatives "close to the people” (volksverbunden) in an ostensibly still fully direct democracy.

Suburbanization as the new culprit fit particularly well to the situation in Geneva, where turnout rates had always been comparatively low compared to other cantons and were now in continuous decline. In a first of its kind research project commissioned by the Canton of Geneva at the end of the 1960s, Roger Girod thus developed this argument further by looking at the varying importance of social norms and the social pressure enforcing them in rural and urban settings. Since the 1940s, surveys had revealed the importance of social norms surrounding voting: respondents commonly overestimated their tendency to vote in their responses. ${ }^{51}$ Inspired by the environmental approach developed by Paul Lazarsfeld and his 
team at the University of Chicago since the 1940s, Girod emphasized the role of "opinion leaders” in getting people to vote - beginning with the neighbor you meet on your way to the voting booth. Precisely these forms of social pressure were lacking in urban, "anonymized” environments. $^{52}$

\section{Female participation: The "unknown" after female enfranchisement}

The late introduction of female suffrage in 1971 further disturbed this ideal of small-scale democracy, since it practically doubled the electorate overnight. Certainly, the concept of female suffrage had become accepted among most (overwhelmingly male) party officials during the 1960s, and a large majority of male voters (66\%, with 58\% turnout) approved passive and active voting rights for women in February 1971. Since the 1950s, societal change and the process of European integration had turned the exceptionalist argument around: both for the sake of Switzerland's self-image and its foreign policy, the country could not appear retrograde in comparison with other (Western) democracies. ${ }^{53}$

Nonetheless, female enfranchisement did not obliterate the arguments discussed during the decade-long debate over its advisability, including the question of whether or not women would want to vote in the first place, nor did the construct of a gender-based divide between "private" and "public" spheres fully disappear. ${ }^{54}$ Anti-suffragists - among them a handful of female activists - had long argued that women were not interested in politics and would simply not vote, despite the fact that the few informal "consultations” of Swiss women about their own enfranchisement had proven inconclusive. ${ }^{55}$ Even the Federal Council, now in favor of female suffrage, had used the same argument at the end of the 1950s to reassure men that female suffrage would not change much in Swiss politics - in other democracies, women voted less than men on average. ${ }^{56}$ While the debate was still ongoing at the federal level, first “female votes" provided a full-scale test for the willingness (and the capability) of Swiss women to vote, as some cantons and cities introduced female suffrage starting in 1959. As 
much as journalists and political scientists wanted straightforward statistics, it proved difficult to generalize about female turnout, since only cantons and cities where authorities had organized gender-separated electoral registers or gender color-coded voting cards could distinguish between male and female voter turnout. ${ }^{57}$ Elsewhere, it was only possible to compare the results with the previous male-only ballot. Still, each case of under-average female turnout made the headlines, especially in cantons and cities without female suffrage. ${ }^{58}$ In reaction, suffragist associations urged Swiss women to vote where they had the right to and attempted to relativize the importance of these first experiences. ${ }^{59}$ Indeed, feminists just as political scientists referred to historical electoral statistics to recall how male universal suffrage in 1848 had also not engendered a massive male participation. ${ }^{60}$

After Swiss men voted for female enfranchisement in February 1971, female abstention became the new "unknown" of the upcoming votes. ${ }^{61}$ To some extent, this question was one of the last concerns about female suffrage that remained socially acceptable to express after enfranchisement occurred. The relevance of gender-based electoral statistics was debated all the more vociferously since female enfranchisement in Switzerland materialized at a time when statistical forms of knowledge, based on demographics and polls, were becoming both ubiquitous and open to question. ${ }^{62}$ In the run-up to the first elections of 1971 open to women, suffrage activists thus denounced gender-based electoral statistics as continued gender discrimination. What could justify such a practice, when any differentiation between men, for instance based on profession, was forbidden in view of ballot secrecy? ${ }^{63}$ Swiss women were now "full citizens" and an integral part of the demos, as citizenship education brochures addressed to women now asserted: "The Swiss people: you too count as one of them." 64 In response to lobbying by the statistical bureaus and a number of political scientists, the Federal Chancellery considered asking the cantons to count female turnout or even party preference separately. It yet soon dropped this plan, wary of any bad press: women should not feel 
“under surveillance.”65 Federal Councilor Hans-Peter Tschudi even assured the historically suffragist journal Schweizer Frauenblatt that gender-based electoral statistics were out of the question. ${ }^{66}$ Still, some cantons decided to count female turnout separately, while respecting ballot secrecy on party preference. As one Neuchâtel Canton executive explained to a feminist newspaper, these numbers were of public interest, since "as you know, the authorities have a duty to invite all citizens from all possible backgrounds to go to the ballot box." ${ }^{\text {"67 Knowing }}$ about turnout was thus a prerequisite for taking political measures in its favor. However, the precarious nature of the statistics collected made it hard for statisticians to categorically attribute the rise of abstentions between 1967 and 1971 "only to women" (from 34.3\% to 43.1\% of the eligible voting population), as a statistician for the Christian Democrats admitted. A "declining willingness to participate" could be observed in the entire population. $^{68}$

\section{The "symptom" of a "democratic unease"}

For many commentators, including political scientists, the first female votes carried a massive symbolic significance because they could supposedly redynamise Swiss democracy as a whole. ${ }^{69}$ Fears over female abstention were not simply about women’s political behavior but mirrored a widespread concern over an apparent state of "democratic unease” among male citizens. ${ }^{70}$ First coined by the liberal constitutionalist Max Imboden to describe Swiss democracy in a "strange middle-ground between unbroken self-confidence and nagging doubt,"71 the phrase had circulated widely among Swiss intellectuals, journalists and politicians since the mid-1960s, at a time of widespread change and increased European and international openness. In this narrative, abstention often served as a clear-cut "symptom" for Swiss democracy’s “sickness.”72 No longer merely an individual shortcoming, abstention had become a "social problem" politicians used this diagnosis to plead for a new constitution to "modernize" Swiss 
democracy. Beyond differences of opinion on concrete changes, for instance on the extension of direct-democratic procedures, a common reformist argument maintained that there was a need to awaken the interest of citizens in "politics," particularly among the youth. ${ }^{74}$ Neither the new and often spectacular forms of activism emerging at the end of the 1960s, nor the rise of new xenophobic movements did much to change this diagnosis of a passive citizenry. At the very least, as a parliamentarian of the Evangelical People’s party pointed out, "extremist" movements were only a problem because the "silent majority" was becoming larger - in Switzerland, Nixon's phrase commonly served to refer specifically to non-voters. ${ }^{75}$ In contrast, American scholars had either reacted to the movements surrounding 1968 by warning against too much participation, as did the above-mentioned report for the Trilateral Commission, or by advocating to extend the study of political participation to social movements, including earlier ones, such as the civil rights movement. ${ }^{76}$

\section{"Fighting" abstention?}

As turnout continued to decline in the 1970s, and while the debate on a new constitution lingered, many politicians agreed that it was urgent (and perhaps more feasible) to consider measures to curb abstention. Turnout rates of roughly $50 \%$ in federal elections were not simply a symptom of crisis anymore; they had become the crisis in and of itself, namely a “crisis of government,” as Federal Councilor Willy Ritschard stated in 1975. At the cantonal and federal level, parliamentarians raised motions to find answers and solutions about the "deficits” of direct democracy uncovered by abstention. ${ }^{77}$ Following the Geneva study in the late 1960s, a series of scientific studies were commissioned to better understand and, ultimately, help curb abstention. Even if everyone publicly addressing the topic also had an opinion on it, academic research appeared necessary to better grasp its causes. Political scientists were now recognized as the main experts on the subject, with electoral statisticians and pollsters supporting their work. The growing political demand for knowledge about 
abstention thus coincided squarely with the establishment of Swiss political science as an independent discipline; the funds and visibility granted to major political scientists further legitimized them in the academic arena as well as in the public sphere.

Yet the normative and oftentimes monocausal approach favored by politicians toward abstention now contrasted strongly with the professional neutrality common among Swiss political scientists. Contrary to media reports, ${ }^{78}$ disapproving judgments on abstention as a form of "laziness" had long disappeared from their studies. While Swiss political science remained pluralistic and maintained proximity to historical research, many publications now adopted a positivist, ahistorical perspective - inspired by behaviorism - on individual political behavior. Polling was considered the state of the art methodology required for such an approach, as well as becoming ubiquitous in politics and in the media. The first nationwide polling studies launched at the beginning of the 1970s drew a completely different picture than the crisis diagnosis made by the politicians - or than later reconstructions by historians. ${ }^{79}$ A major 1972 study on Swiss political attitudes, which drew inspiration from the pioneering studies by American political scientists Gabriel A. Almond and Sidney Verba on political culture, thus concluded that the Swiss were mostly satisfied with their democracy and oriented toward social peace, with the exception of some "revolutionaries." 80 Indeed, Switzerland fared better on satisfaction indexes than most democracies. For its authors, these results confirmed the assessment of intellectual Denis de Rougemont a decade earlier that the Swiss were a "happy people" - thereby eliding the more critical aspects of his work on the need to open Swiss democracy to European integration. ${ }^{81}$

The reports commissioned at the federal level reflect the difficulty for political scientists to paint the monochromatic picture of non-voters expected by politicians. The federal government commissioned Leonhard Neidhart, professor for political science, and Jean-Pierre Hoby, a young doctor of sociology, to study the causes of abstention and to find out "the 
extent to which negative attitudes toward political institutions might play a role." ${ }^{82}$ While their study also relied on a survey of 200 "representative” citizens across the whole country, Neidhart and Hoby warned against the "illusory impression that the issue presented by the research mandate could, akin to an election projection poll, be settled once and for all.” ${ }^{83}$ With their common interest in sociological and institutional factors, they attempted to find a balance between individual and collective causes. Beyond the social changes identified by Girod and Steiner, many institutional aspects specific to Switzerland could explain nonvoting: the frequency of votes, the relatively low stakes of most elections and some referenda. Setting these nuances aside, the media reception of the study focused instead on the psychological - and thus individual - "motivations” highlighted by the study: mostly "political indifference," then a "feeling of incompetence," followed by a "unilateral orientation toward private life," and "trust in the authorities." ${ }^{44}$ While this last result corresponded to the findings of the 1972 study on the overall contentment of the Swiss, it was also little commented upon in the media. Editorials, but also speeches by politicians at official events still linked abstention, for the most part, to social change and particularly to the loss of “civic values" in the younger generations. ${ }^{85}$ With variations in tone and judgment, many takes on non-voters revealed an ideal (male) citizenship as a photographic negative: a voting, informed, loyal and trusting citizen. Not unlike the discussion in the 1950s, which had conjured up an ideal male voter, male elites of the 1970s mourned the alleged loss of his hegemony.

The federal government then commissioned a working group to draft measures to curb abstention. The group (all men, supported by a female secretary, almost all from Germanspeaking cantons) gathered together political scientists (among them Leonhard Neidhart), state administrators at the federal and cantonal level, a representative of the labor unions and a leading journalist. ${ }^{86}$ Their report employed even greater caution in warning against 
"exaggerated expectations" in the "efficacy of possible counter-measures" regarding a phenomenon that still called for much further research. ${ }^{87}$ In any case, the "realm of realistic measures" appeared limited, since "abstention is to a certain extent intrinsically tied to our specific Swiss democracy, which we all, or at least the majority of the Swiss people, do not want to lose, despite its shortcoming and flaws." ${ }^{88}$ Swiss exceptionalism now appeared as a holy threat. The report thus immediately set aside possible reforms such as the introduction of a majority voting system - despite the fact that the working group had purposefully engaged in brainstorming so as to encompass a wide range of solutions. ${ }^{89}$ Instead, the working group settled on smaller measures meant to facilitate and motivate voting. For the former, voting by mail was to be particularly encouraged at all federal levels. To motivate greater voter turnout, the report recommended better information on upcoming votes from the state, civil society and the media, increased efforts on the subject of citizenship education and symbolic rewards for regular voters. Indeed, in reference to behaviorist psychology, ${ }^{90}$ they recommended rewards instead of coercive measures - such as prizes or aperitifs served in the voting booth. In the few cantons where it still existed, compulsory voting enforced by a means of fines, had become increasingly contested. ${ }^{91}$ The experts may have recognized this opposition as one of the signals that coercion, injunctions or even moral calls to do one’s “duty" and vote had lost ground among Swiss voters, even if no social movement actively called them to abstain. Young people increasingly opposed authoritarian discourses on voting as a moral duty at school or during “citizenship ceremonies” (Jungbürgerfeier). ${ }^{92}$ Even the very foundation of the citizen-soldier model could no longer be taken for granted: the entry of women into politics invalidated its androcentrism. Throughout their fight for suffrage, Swiss feminists had contributed to an uncoupling of citizenship from soldiering. Since the 1960s, conscientious objectors had also made visible the rejection of compulsory military service for men. ${ }^{93}$ 
With the publicization of the issue through the medialization of the various reports, "ordinary" citizens now claimed their own voice on the matter. Beyond the rare article or street interview asking non-voters to explain their abstention, ${ }^{94}$ citizens with no recognized expertise on the subject were rarely invited to the discussion table. Voters and non-voters alike now sent letters to the media or the authorities of their own volition, proposing their own interpretations of the phenomenon. Some dutiful voters reinforced the common lamentation against non-voters by asking for more forceful measures, particularly financial sanctions. ${ }^{95}$ Others faulted politicians for their "appalling mediocrity." 96 As much as some journalists themselves were increasingly weary of "non-voter bashing” (Nichtwählerschelte), they also rejected the categorical blame heaped on politicians for the alienation (Entfremdung) of many citizens from the state. ${ }^{97}$ A series of ready-made expressions, often reproduced in SwissGerman dialect for added authenticity, circulated between the interventions made by citizens interventions, the takes published by journalists and, incidentally, the questionnaires used by political scientists and pollsters: "those at the top do whatever they want," "only a few people decide in politics." 98 Whether or not they circulated widely among citizens, their use as ostensibly popular wisdom revealed a tension between representatives and the represented that was normally brushed aside by the usual depictions of a direct-democratic, horizontal polity. And despite political admonitions that the Swiss people were the government, as Willy Ritschard intoned in 1975, the mere visibility of turnout rates at each vote revealed the constructed and changing character of the concepts of "the people" and "the people's will" that referenda were supposed to make manifest.

\section{Conclusion: A knowledge-fueled helplessness?}

These cognitive dissonances about the nature of Swiss democracy itself may explain why the public debate on non-voting finally escaped from the grasp of its initiators. While the "problem" of abstention remained on the agenda, the various studies and reports - a product 
of the "culture of reports and counter-reports" induced by scientification ${ }^{99}$ - did not produce a substantial “cure.” Even the very interpretation of non-voting was becoming more and more contested. At the turn of the 1980s, a new generation of political scientists shifted the debate by extending the concept of political participation to areas beyond mere voting, following a turn in international participation research. ${ }^{100}$ They suggested that the new social movements were providing dissatisfied citizens with alternative forms of participation. While many journalists had concluded that the official reports were useless, knowledge on abstention was still in demand, and thus these studies continued to circulate widely in the media. ${ }^{101}$ They were forcefully contradicted both by conservative politicians and experts on non-voting, including Leonhard Neidhart, who dismissed the legitimacy of the new social movements as legitimate political actors. ${ }^{102}$ The tendency displayed by journalists to downplay the critical tone of these studies was further evidence that they had hit a nerve. To illustrate a study by Hanspeter Kriesi and Gilbert Ganguillet, which compared non-voters to "stateless" or "homeless" citizens and highlighted the dysfunctionality of certain features of the political parties, the popular French-speaking weekly L'Hebdo published a cartoon mocking both a pompous (male) politician and a bored (also male) citizen wearing a cap bearing the cross of the Swiss flag. ${ }^{103}$ After almost a decade of knowledge production, the "non-voter” remained a (male) stereotype conjured to question the loyalty of the Swiss to their state.

In the end, the numerous academic and commercial studies dedicated to understanding the decline in turnout did little to quell the relative helplessness of politicians and journalists facing fundamental changes in Swiss democracy. The decline in voter turnout challenged dominant understandings of political participation, which centered on voting and was modeled on the ideal of a (male) citizen-soldier. At the same time, the emphasis on nonvoting led politicians and journalists, but also political scientists to neglect major transformations in Swiss democracy, from female suffrage to the rise of new social 
movements proposing alternative forms of participation. Paradoxically, while the political demand for expertise legitimized pollsters and political scientists, their interpretations of nonvoting did not always make it to a wider audience. The often univocal perspective held by politicians and journalists increasingly contrasted with the multiple explanatory paradigms on abstention developed by political scientists, but also with the seldom heard voices of nonvoters. This dissonance points to a fundamental power imbalance in the production of knowledge on voter turnout and its circulation in the public sphere, separating not only those who vote from those who do not, but also those who get to speak about abstention and those who - the non-voters - are spoken of.

A similar unequal distribution of legitimized speech on non-voting remains observable in contemporary Switzerland as well as in other democracies. ${ }^{104}$ Yet exceptionalist narratives praising Swiss democracy have made a stunning comeback in Switzerland since the 1990s, pushed first by the radicalized Swiss People's Party (SVP) claiming to protect the country from European integration. ${ }^{105}$ This shift coincided with the emergence of durable crisis narratives concerning the European Union itself as well as neighboring democracies such as Italy, France and Germany. ${ }^{106}$ In contrast, Swiss political scientists and the media have mostly left the crisis diagnosis of earlier decades behind them, ${ }^{107}$ although turnout rates have only increased slightly since the 1980 s. $^{108}$ Whereas earlier discussions had problematized a possible threshold of 50\% voter turnout, the populist emphasis encouraged by the SVP on the "people” and the "people's will” at each vote may have contributed to making invisible the constantly shifting boundaries within that fictional "people” between voting and non-voting citizens. Moreover, the SVP's emphasis on an exclusive understanding of citizenship has contributed to limiting both access to Swiss citizenship and to voting rights for the growing non-Swiss segment of the population (25.1\% of the resident population in 2019). ${ }^{109}$ While some political theorists point to a "democratic deficit" in this area, ${ }^{110}$ there are new demands 
in public debates for expertise on the participation of foreigners - an echo of the previous worries over women’s abstention. ${ }^{111}$ 
1 “Plädoyer Bundesrat Ritschards gegen die Resignation” Neue Zürcher Zeitung, March 24, 1975. Participation in federal parliamentary elections had reached $80 \%$ in the 1920 s, dropped to $70 \%$ in the 1940 s and was nearing $50 \%$ of the eligible voting population in the 1970 s (registration on the electoral roll has been mandatory in Switzerland since the end of the nineteenth century). With fluctuations depending on the issue at stake, direct-democratic votes also experienced an overall decline in turnout. Leonhard Neidhart, "Stimm- und Wahlbeteiligung,” Historisches Lexikon der Schweiz, 2017.

2 Neidhart, "Stimm- und Wahlbeteiligung."

${ }^{3}$ As another Federal Councilor (Kurt Furgler, Christian-Democratic Party) declared in a TV interview two years later, TV-Statement für CH-Magazin, E4110B\#1989/31\#10*, Swiss Federal Archives (SFA).

${ }^{4}$ Colin Crouch, Post-Democracy (Cambridge: Polity Press, 2004); Pierre Rosanvallon, La Contre-Démocratie. La politique à l'âge de la défiance (Paris: Seuil, 2014).

${ }^{5}$ A central reference here is Carole Pateman, Participation and Democratic Theory (Cambridge: Cambridge University Press, 1970). See Ingrid Gilcher-Holtey, "Political Participation and Democratization in the 1960s: The Concept of Participatory Democracy and its Repercussions," in Democracy in Modern Europe. A Conceptual History, ed. Jussi Kurunmäki, Jeppe Nevers and Henk te Velde (New York: Berghahn, 2018), 257-280; for Switzerland, see Damir Skenderovic and Christina Späti, Die 1968er-Jahre in der Schweiz: Aufbruch in Politik und Kultur (Baden: Hier + Jetzt, 2012).

${ }^{6}$ The Trilateral Report was published as a book the same year. Michel Crozier, Samuel P. Huntington and Joji Watanuki, The Crisis of Democracy: On the Governability of Democracies (New York: New York University Press, 1975), 113 and 12.

${ }^{7}$ These interpretations usually come along a more central argument on the end of a specific postwar economic equilibrium; see Wolfgang Streeck, How Will Capitalism End? Essays on a Failing System (Brooklyn: Verso, 2016).

${ }^{8}$ Jan-Werner Müller, Contesting Democracy: Political Ideas in Twentieth-Century Europe (New Haven, CT: Yale University Press, 2013); Martin Conway, "Democracy in Western Europe after 1945,” in Democracy in Modern Europe. A Conceptual History, ed. Jussi Kurunmäki, Jeppe Nevers and Henk te Velde (New York: Berghahn, 2018), 231-256.

${ }^{9}$ Claudia Christiane Gatzka, Die Demokratie der Wähler: Stadtgesellschaft und politische Kommunikation in Italien und der Bundesrepublik 1944-1979 (Düsseldorf: Droste Verlag, 2019).

${ }^{10}$ For the French Third Republic, see Yves Déloye, "La construction politique d'une « science électorale » en France sous la IIIe République. Facteurs et acteurs d'un métissage politicoscientifique,” Revue internationale de politique comparée 19 (2012): 37-66.

${ }^{11}$ Lutz Raphael, "Die Verwissenschaftlichung des Sozialen als methodische und konzeptionelle Herausforderung für eine Sozialgeschichte des 20. Jahrhunderts,” Geschichte und Gesellschaft 22 (1996): 165-193; "Verwissenschaftlichung von Politik nach 1945," Archiv für Sozialgeschichte 50 (2010).

${ }^{12}$ I constructed my corpus by looking for books and journal articles focusing on "Stimmbeteiligung," "Stimmabstinenz" or "abstentionnisme.” The same keywords proved equally helpful for following the framing of non-voting in the media, using collections of digitized newspapers as well as press clippings. See Zoé Kergomard, "Out of the comfort zone. Digitized newspapers as a probe and an incentive for more reflexivity," in Digitized newspapers - a new Eldorado for historians?, ed. Estelle Bunout, Frédéric Clavert and Maud Ehrmann (forthcoming). 
${ }^{13}$ Philippe Gottraux, Pierre-Antoine Schorderet and Bernard Voutat, La science politique suisse à l'épreuve de son histoire: genèse, émergence et institutionnalisation d'une discipline scientifique (Lausanne: Réalités sociales, 2000).

${ }^{14}$ Thomas S. Eberle and Kurt Imhof, Sonderfall Schweiz (Zürich: Seismo, 2007); Georg

Kreis, “Sonderfall," Historisches Lexikon der Schweiz, 2012.

${ }^{15}$ André Siegfried, La Suisse, démocratie-témoin (Neuchâtel: Baconnière, 1948).

${ }^{16}$ About the theorization of a "consensus" or "concordance" model, see Elie Burgos, Oscar Mazzoleni and Hervé Rayner, La formule magique: Conflits et consensus partisans dans l'élection du Conseil fédéral (Lausanne: Presses Polytechniques et Universitaires Romandes, 2011), 107-127.

17 “Notes d'un passant. Le père Piquerez,” L'Impartial, 29 October 1947.

${ }^{18}$ Zoé Kergomard, Wahlen ohne Kampf? Schweizer Parteien auf Stimmenfang, 1947-1983 (Basel: Schwabe, 2020), 85-89.

${ }^{19}$ Statistisches Amt des Kantons Zürich, ed., Die Nationalratswahlen 1943 im Kanton Zürich (Zürich: Statistisches Bureau des Kantons Zürich, 1944).

${ }^{20}$ On the history of statistics in Switzerland, see Hans-Ulrich Jost, Von Zahlen, Politik und Macht. Geschichte der schweizerischen Statistik (Zürich: Chronos, 2016).

${ }^{21}$ Zurich Socialist Party: "Willst DU deinen Gegner wählen, musst DU an der Urne fehlen!,“ Pamphlet, [1947], Ar 1.230.3, Swiss Social Archives (SSA).

${ }^{22}$ Robert Grimm, Executive committee of the Swiss Socialist Party, 30 October 1947, Ar 1.111.11, SSA. The German Social Democrats also launched a study with the aim of mobilizing working-class non-voters in 1965. See Anja Kruke, “'Responsivität' und Medialisierung. Meinungsforschung für Parteien in den 1960er Jahren,” in Medialisierung und Demokratie im 20. Jahrhundert, ed. Frank Bösch and Norbert Frei (Göttinge: Wallstein 2006), 145-178.

${ }^{23}$ Statistisches Amt des Kantons Zürich, ed., Die Nationalratswahlen 1943 im Kanton Zürich, 265.

${ }^{24}$ Statistisches Amt des Kantons Zürich, ed., Die Nationalratswahlen 1943 im Kanton Zürich, 279.

${ }^{25}$ Gustav Erhard and Raymond Deonna, Die Stimmenthaltung als Staatspolitische Gefahr (Zürich: Aktionsgemeinschaft Nationaler Wiederaufbau, 1945).

${ }^{26}$ Erhard and Deonna, Die Stimmenthaltung als Staatspolitische Gefahr, 8; Charles Edward Merriam and Harold F Gosnell, Non-Voting: Causes and Methods of Control (Chicago, IL: The University of Chicago Press, 1924).

${ }^{27}$ For instance Bernard R. Berelson, Paul F. Lazarsfeld and William N. McPhee, Voting: A Study of Opinion Formation in a Presidential Campaign (Chicago, IL: University of Chicago Press, 1954), 314; Herbert McClosky, "Consensus and Ideology in American Politics," American Political Science Review 58 (1964): 376.

${ }^{28}$ Statistisches Amt des Kantons Zürich, Die Nationalratswahlen 1943 im Kanton Zürich, 270.

${ }^{29}$ Statistisches Amt des Kantons Zürich, Die Nationalratswahlen 1943 im Kanton Zürich, 273, 267, 270.

30 “A la ligue du Gothard,” Tribune de Lausanne, November 21, 1943.

${ }^{31}$ Regula Ludi, "Gendering citizenship and the state in Switzerland after 1945," in Nation and Gender in Contemporary Europe, ed. Vera Tolz and Stephenie Booth (Manchester:

Manchester University Press, 2005), 53-79.

${ }^{32}$ In the context of the wars of independence wars in its colonial empire in the 1950s, French political parties and the French media also commonly framed voting and non-voting in a military light, depicting non-voting as “desertion” or even “treason.” Zoé Kergomard, “Die 
Wahlenthaltung als demokratische „Krankheit“? Politische Eliten, Nichtwählerinnen und Nichtwähler in Frankreich in der Nachkriegszeit (1944-1989),” Heuss-Forum 10 (2019).

${ }^{33}$ See Yvonne Voegeli, Zwischen Hausrat und Rathaus: Auseinandersetzungen um die politische Gleichberechtigung der Frauen in der Schweiz, 1945-1971 (Zurich: Chronos, 1997).

${ }^{34}$ Statistisches Amt des Kantons Zürich, eds., Die Nationalratswahlen 1943 im Kanton Zürich, 280.

${ }^{35}$ Roger Girod, “Facteurs de l'abstentionnisme en Suisse,” Revue française de science politique 3 (1953): 349-76, at 350.

${ }^{36}$ Girod, "Facteurs de l'abstentionnisme en Suisse," 249.

${ }^{37}$ Thibaud Boncourt, "The Transnational Circulation of Scientific Ideas: Importing Behavioralism in European Political Science (1950-1970)," Journal of the History of the Behavioral Sciences 51 (2015): 195-215.

${ }^{38}$ Georg Steinmetz, ed., The Politics of Method in the Human Sciences: Positivism and Its Epistemological Others (Durham London: Duke University Press, 2005); George Steinmetz, "Comparative History and Its Critics: A Genealogy and a Possible Solution," in A Companion to Global Historical Thought, ed. Prasenjit Duara, Viren Murthy and Andrew Sartori (Oxford: John Wiley \& Sons, 2014), 412-36.

${ }^{39}$ Roger Girod, “Facteurs de l'abstentionnisme en Suisse,” Revue française de science politique 3 (1953): 350.

${ }^{40}$ Lester W. Milbrath, Political Participation: How and Why Do People Get Involved in Politics? (Chicago: Rand McNally, 1965).

${ }^{41}$ Jürg Steiner, "Einige Hypothesen zur Stimmbeteiligung," Annuaire de l'Association Suisse de Science Politique = Jahrbuch der Schweizerischen Vereinigung für politische Wissenschaft 3 (1963): 58.

42 Girod, "Facteurs de l'abstentionnisme en Suisse," 355.

${ }^{43}$ TEAM Sozialforschung/ Marketing, Aktualisierung der BGB. Resultate einer Sozialforschung (Zürich: Team Sozialforschung Zürich, circa 1962), Private Archives of the Zurich Swiss People’s Party (SVP), 5.

${ }^{44}$ Girod "Facteurs de l'abstentionnisme en Suisse," p.354.

${ }^{45}$ Arthur William Kornhauser, The Politics of Mass Society (New Brunswick, NJ: Transaction, 1959).

46 TEAM Sozialforschung/ Marketing, Aktualisierung der BGB, 6; Rudolf Fischer, Masse und Vermassung: Versuch einer begrifflichen Klärung (Schopfheim: Uehlin Druck, 1961).

${ }^{47}$ Mario König, "Politik und Gesellschaft im 20. Jahrhundert. Krisen, Konflikte, Reformen," in Eine kleine Geschichte der Schweiz: der Bundesstaat und seine Traditionen, ed. Manfred Hettling (Frankfurt: Suhrkamp, 1998), 82.

${ }^{48}$ Jürg Steiner, Die Beziehungen zwischen den Stimmberechtigten und den Gewählten in ländlichen und städtischem Milieu: Versuch einer staatssoziologischen Untersuchung am Beispiel des Grossen Rates des Kantons Bern (Bern, Stuttgart: Haupt, 1959), 60.

${ }^{49}$ Steiner, Die Beziehungen zwischen den Stimmberechtigten und den Gewählten, 61-62.

${ }^{50}$ Steiner, Die Beziehungen zwischen den Stimmberechtigten und den Gewählten, 78-79.

51 Jürg Steiner, "Ueberprüfung von Interview-Ergebnissen über die Stimm- und Wahlbeteiligung durch amtliche Angaben,” Kölner Zeitschrift für Soziologie und Sozialpsychologie 17 (2) (1965): 234-244.

${ }^{52}$ Paul Felix Lazarsfeld, Bernard Berelson and Hazel Gaudet, The People's Choice: How the Voter Makes Up His Mind in a Presidential Campaign (New York: Duell, Sloan \& Pearce, 1944); Roger Girod and Charles Ricq, "Microsystèmes sociaux et abstentionnisme électoral à Genève,” Schweizerisches Jahrbuch für Politische Wissenschaft 10 (1970): 75 and 79. 
${ }^{53}$ As a popular slogan of suffrage activists highlighted: "Two countries in Europe don't have female suffrage: Portugal and Switzerland, fie, fie!,” Ernst Koehli, 1. Mai Umzug in Zürich, 1 May 1956, F 5144-1401-Nb-002, SSA.

${ }^{54}$ Brigitte Studer, “'L’Etat c'est l’homme.' Politique, citoyenneté et genre dans le débat autour du suffrage féminin après 1945," Schweizerische Zeitschrift für Geschichte 46, no. 3 (1996): 356-382.

55 Peter Frey, L'opinion publique et les élites face au suffrage féminin en Suisse particulièrement dans les villes de Genève et de Zurich (1920-1960) (Geneva: University of Geneva, 1970).

${ }^{56}$ Conseil fédéral, "Message du Conseil fédéral à l’Assemblée fédérale sur l'institution du suffrage féminin en matière fédérale (du 22 février 1957),” Bundesblatt, March 7, 1957, 782783.

57 “Trois nouveaux parmi les dix élus genevois au Conseil national,” Journal de Genève, October 31, 1967.

58 "La chronique de Pierre Béguin. Abstention féminine,” Gazette de Lausanne, November 2, 1967.

59 “Genève. Union des femmes,” Femmes suisses et le Mouvement féministe 51 (1963);

“Réflexions postélectorales,” Femmes suisses et le Mouvement féministe 80 (1967).

60 "Intéressante comparaison: comment se comportent les électeurs, il y a cent ans...,"

Femmes suisses et le Mouvement féministe 51 (1963); Roland Ruffieux, "Le canton de Vaud et les élections fédérales,” Feuille d'avis de Lausanne, October 27, 1971.

${ }^{61}$ Paul Egger, “Geben die Frauen den Frauen die Stimme?,” Sonntag, 1971. See also Zoé Kergomard, "An die Urnen, Schweizerinnen! Die Erfindung der Wählerin im eidgenössischen Wahlkampf von 1971," in Kultur und Praxis der Wahlen. Eine Geschichte der modernen Demokratie, ed. Hedwig Richter and Hubertus Buchstein (Wiesbaden: VS, 2017), 237-265.

${ }^{62}$ On the contested history of polls in Switzerland, see Koni Weber, Umstrittene Repräsentation der Schweiz: Soziologie, Politik und Kunst bei der Landesausstellung 1964 (Tübingen: Mohr Siebeck, 2014); Zoé Kergomard, Wahlen ohne Kampf?, 95-104.

63 "Pour ou contre: la statistique des votants par électeurs et électrices," Femmes suisses et le Mouvement féministe 59 (1971).

${ }^{64}$ Hugo Götz and Walter Grieder, Grünes Licht für Eva: Staatskundliches Brevier für die Schweizerin (Basel: Staatskunde-Verlag, 1971).

${ }^{65}$ Meeting of the working group for the introductory brochure to politics for women, 26 April 1971, E1010B\#1986151\#606, SFA.

66 “Keine getrennte Angabe der Stimmbeteiligung von Männern und Frauen!” Schweizer Frauenblatt, 1971.

67 "Pour ou contre."

${ }^{68}$ Heinz Niemetz, Die Nationalratswahlen 1971: Eine Statistische Grobanalyse (Bern: Christlichdemokratische Volkspartei der Schweiz, 1972).

${ }^{69}$ Ruffieux, Roland: Le canton de Vaud et les élections fédérales, in: Feuille d'avis de Lausanne, October 29, 1971.

${ }^{70}$ Max Imboden, Helvetisches Malaise (Zürich: EVZ-Verlag, 1964).

${ }^{71}$ Max Imboden, Helvetisches Malaise, 6.

${ }^{72}$ For instance Daniel Duc, “La participation civique est-elle contestée?,” Erneuern und beharren. Nationales Jahrbuch der Neuen Helvetischen Gesellschaft 41 (1970): 78-92.

${ }^{73}$ In the sense of Malcolm Spector and John I. Kitsuse, Constructing Social Problems (New York: Routledge, 2017). 
${ }^{74}$ About the reform discussion in the 1960s, Georg Kreis, "Die Lancierung der Totalrevision der Bundesverfassung in den 1960er Jahren," in Dynamisierung und Umbau: die Schweiz in den 60er und 70er Jahren, ed. Mario König et al. (Zürich: Chronos, 1998), 21-50.

${ }^{75}$ Heinrich Schalcher, "Postulat Schalcher. Aktivierung der schweigenden Mehrheit,“ Amtliches Bulletin der Bundesversammlung, March 16, 1972, 373-376.

${ }^{76}$ David Easton, "The New Revolution in Political Science," The American Political Science Review 63 (1969): 1051-1061; Sidney Verba and Norman H. Nie, Participation in America: Political Democracy and Social Equality (University of Chicago Press, 1972).

${ }^{77}$ Heinrich Schalcher, "Postulat Schalcher”; Rolf Weber, "Postulat Weber-Arbon. Stimmbeteiligung,” Amtliches Bulletin der Bundesversammlung, December 12, 1975, 379_ 380.

78 “Stimmbürger im Streik?,” Wir Brückenbauer, December 3, 1976.

${ }^{79}$ For instance Peter Hablützel, "Regierungsparteiengespräche im schweizerischen Konkordanzsystem,” SVPW Jahrbuch = Annuaire ASSP 26 (1986): 273-288.

${ }^{80}$ Dusan Sidjanski, "Environnement politique en Suisse," in Les Suisses et la politique: enquête sur les attitudes d'électeurs suisses, 1972, ed. Dusan Sidjanski (Bern: Peter Lang, 1975), 1.

${ }^{81}$ Dusan Sidjanski, “Introduction,” in Les Suisses et la politique, vii; Denis de Rougemont, La Suisse ou L'histoire d'un peuple heureux (Paris: Hachette, 1965).

${ }^{82}$ Leonhard Neidhart and Jean-Pierre Hoby, Ursachen der gegenwärtigen Stimmabstinenz in der Schweiz (Zürich: Eidgenössisches Justiz- und Polizeidepartement, 1977), i.

${ }^{83}$ Neidhart and Hoby, Ursachen der gegenwärtigen Stimmabstinenz, i.

84 "Votations: pourquoi les Suisses s'abstiennent-ils de plus en plus?,” L'Express, July 8, 1977.

85 "Elections fédérales. Les absents ont tort,” Journal de Genève, October 23, 1979; “Opinion. Le prêche du Président,” L'Impartial, January 3, 1976.

${ }^{86}$ Eidgenössisches Justiz- und Polizeidepartement, Massnahmen zur Erhöhung der Stimmund Wahlbeteiligung in der Schweiz (Bern: Eidgenössisches Justiz- und Polizeidepartement, 1979), 2.

${ }^{87}$ Eidgenössisches Justiz- und Polizeidepartement, Massnahmen, 1.

${ }^{88}$ Eidgenössisches Justiz- und Polizeidepartement, Massnahmen, 1.

${ }^{89}$ Forged at the intersection of the military and economics, the concept of brainstorming had been circulated widely in Western Europe since the end of the 1950s. In Switzerland, the closeness of economic, political and military elites contributed to the dispersal of such practices from business into state administrations. See Bregje F. Van Eekelen, "Creative Intelligence and the Cold War: US Military Investments in the Concept of Creativity, 19451965," Conflict and Society 3 (2017): 92-107; Bregje F. Van Eekelen, "Knowing Otherwise: The Transatlantic Travels of Creative Thinking Expertise in the 1950s," History of Knowledge (blog), May 31, 2019, https://historyofknowledge.net/2019/05/31/knowing-otherwise.

${ }^{90}$ Bernard Berelson and Gary A. Steiner, Human Behavior. An Inventory of Scientific Findings (New York, NY: Harcourt, Brace \& World, 1964).

${ }^{91}$ Between the 1960s and the 1980s, eight cantons have abolished financial sanctions. Only Schaffhausen has maintained it to the present day. Silvio Bircher, "Das Problem des Stimmzwangs im Kanton Aargau," Aargauisches Beamtenblatt 68 (1971): 13-18; Michael M. Bechtel, Dominik Hangartner and Lukas Schmid, "Does Compulsory Voting Increase Support for Leftist Policy?,” American Journal of Political Science 60 (2016): 752-767.

92 “Erzwungene Diskussion an der Jungbürgerfeier,” Neue Zürcher Zeitung, November 25, 1968. 
${ }^{93}$ Niels Rebetez, "Comment en vient-on à refuser le service militaire en Suisse. Analyse de récits d'objecteurs des années 1960 et 1970," Trajectoires. Travaux des jeunes chercheurs du CIERA, 2018, http://journals.openedition.org/trajectoires/2529/.

94 “Les abstentionnistes s'expriment," Gazette de Lausanne, November 2, 1967.

95 “Et si l’on punissait les abstentionnistes?,” Journal de Genève, October 29, 1979.

96 “L’affligeante médiocrité de notre personnel politique,” Journal de Genève, October 29, 1979.

97 “Wählerschelte statt Parteitag,” Basler Zeitung, September 5, 1983.

${ }^{98}$ Testmark AG Zürich, Die Frau an den Nationalratswahlen: August 1971 (Zurich: Testmarkt AG, 1971).

${ }^{99}$ Lutz Raphaël, “Die Verwissenschaftlichung des Sozialen,” 178.

${ }^{100}$ Hanspeter Kriesi et al. (ed.), Politische Aktivierung in der Schweiz, 1945-1978

(Diessenhofen: Rüegger, 1981); Erich Gruner, Der Stimmbürger und die “neue” Politik: wie reagiert die Politik auf die Beschleunigung der Zeitgeschichte? (Bern: Haupt, 1983).

${ }^{101}$ Paul Ehinger, "Das verworrene Schicksal eines 'Berichts',” Berner Zeitung, February 8, 1981.

102 “Theoretischer Aktivismus über politische 'Aktivierungsereignisse' in der Schweiz,” Neue Zürcher Zeitung, December 15, 1981; “Wie ist Politik heute (noch) möglich?,” Der Bund, September 5, 1981.

${ }_{103}$ Gilbert Ganguillet and Hanspeter Kriesi, "Der heimatlose Bürger im Leistungsstaat," Schweizerisches Jahrbuch für Politische Wissenschaft 23 (1983): 141-160.

${ }^{104}$ For a similar discussion on contemporary France, see Denis Barbet, "Quand les mots de l'abstention parlent des maux de la démocratie,” Mots. Les langages du politique (2007): 5367.

${ }^{105}$ Alexandre Dézé and Michaël Girod, "Le Sonderfall en péril. Les figures de la menace dans les messages graphiques de l'Union démocratique du centre,” Mots. Les langages du politique (2006): 23-34; Oscar Mazzoleni, Nationalisme et populisme en Suisse: la radicalisation de la "nouvelle" UDC (Lausanne: Presses polytechniques et universitaires romandes, 2008).

${ }^{106}$ See for instance Wolfgang Merkel, "Is There a Crisis of Democracy?,” Democratic Theory 1 (2014): 11-25.

${ }^{107}$ Andreas Ladner, "Politische Parteien," in Handbuch der Schweizer Politik: Manuel de la politique suisse, eds. Peter Knoepfel et al. (Zürich: NZZ-Libro, 2014), 53-85.

${ }^{108}$ From a low point of $42.2 \%$ during the 1995 federal parliamentary elections to $45.1 \%$ in 2019. Similarly to the situation in Germany since the mid-2010s, political scientists have argued that the polarization of politics induced by radical-right challengers has contributed to the increase in abstention.

${ }^{109}$ Die Bevölkerung der Schweiz 2018 (Neuchâtel: Bundesamt für Statistik, 29 November 2019): 1.

${ }^{110}$ Andreas Glaser (ed.), Politische Rechte Für Ausländerinnen Und Ausländer? (Zürich:

Schulthess, 2017); Andrea C. Blättler, Joachim Blatter and Samuel D. Schmid, "Bedenkliches

Demokratiedefizit der Schweiz: Ein Viertel der Bevölkerung ist von demokratischer

Mitbestimmung ausgeschlossen,” DeFacto, 2016, www.defacto.expert/2016/10/18/demokratiedefizit/.

111 "La faible participation des étrangers au premier tour des élections communales

genevoises: interview de Nenad Stojanovic,” Forum, RTS La Première, April 11, 2020. 